\title{
The Ultrastructure of the Cell Wall of Bacillus megaterium
}

\author{
By M. V. NERMUT \\ Institute of Virology, Czechoslovak Academy of Sciences, Bratislava
}

(Accepted for publication 30 June 1967)

\begin{abstract}
SUMMARY
The architecture of the cell wall of Bacillus megaterium strain $\mathbf{M}$ was studied by using electron microscopy of shadowed or negatively stained preparations, ultrathin sections and simple chemical methods. No conspicuous visible structure was found on the surface of whole organisms, isolated cell walls or the 'mucopeptide membranes'. Hot formamide treatment decreased the thickness of cell walls by about $50 \%$, leaving behind a rigid 'mucopeptide membrane'. The removed material is assumed to correspond with the 'teichoic acid' bound presumably by chemical linkage to the rigid layer, thus forming a plastic layer of the cell wall. The total thickness of the cell wall ranged from 200 to $240 \AA$, that of the rigid membranes from 90 to rro $\AA$. Poststaining of glutaraldehyde-fixed organisms or cell walls with osmium tetroxide, potassium permanganate or lead citrate produced a 'triple layered' cell-wall profile. This was not the case with uranyl acetate or phosphomolybdate staining, where the cell wall was represented by one homogeneous and dense track.
\end{abstract}

\section{INTRODUCTION}

The cell wall of Bacillus megaterium consists of two heteropolymers: (a) mucopeptide (or mucopolymer, glycosaminopeptide, murein) and (b) phosphomucopolysaccharide or X-teichoic acid (according to Ghuysen, Leyh-Bouille \& Dierickx, 1962). The voluminous literature about the chemistry of $B$. megaterium cell wall as well as other Gram-positive bacteria has been summarized by Salton (I960, 1964), Work (I96I), Colobert \& Creach (I96I), Rogers (1962) and Martin (I966). Mucopeptide represents the rigid part of the cell wall and is believed to form one bag-shaped molecule, the so-called 'murein sacculus' (Weidel \& Pelzer, 1964). The plastic part of the cell wall is made up of teichoic acid. This is a polyol phosphate containing either ribitol or glycerol, alanine and an amino sugar, e.g. $\mathrm{N}$-acetylglycosamine (in B. megaterium) or N-acetylgalactosamine in staphylococci (Ellwood, Kelemen \& Baddiley, 1963). Archibald, Armstrong, Baddiley \& Hay (196I) claimed that the teichoic acid was bound by salt linkage to the mucopeptide layer. This assumption was based on the fact that it could be extracted by cold trichloroacetic acid. But Ghuysen (196I) with $B$. megaterium and Krause \& McCarty (196I) with streptococci showed that only a part of the teichoic acid was extracted by trichloroacetic acid. Both groups of authors used hot formamide extraction (Fuller, I938) to isolate pure mucopeptide. This suggested that the linkage between teichoic acid and mucopeptide was of covalent nature (Czerkawski, Perkins \& Rogers, I963), namely a phosphodiester (Strominger \& Ghuysen, 1963) or phosphomonoester (Knox \& Hall, 1965). Recently Hay, Archibald \& Baddiley (I965) suggested a phosphoramidate linkage, i.e. between the terminal phos- 
phate group of the teichoic acid and an amino group of a mucopeptide amino sugar. There is less information about the ultrastructural arrangement of these two components. Till now most authors have been satisfied with stating that the cell wall of Gram-positive bacteria stains diffusely and homogeneously and has a thickness of 150-300 $\AA$ or more (see Salton, 1964).

Electron microscopic observations of shadowed as well as positively or negatively stained preparations of cell walls did not reveal any specific or regular arrangement of components (Gerhardt \& Judge, 1964; Salton, 1964). An attempt has been made in the following experiments to clarify the localization and the mutual relationship of the rigid mucopeptide and the plastic teichoic acid layers, and to correlate the morphological findings with the results of chemical analysis (Ghuysen et al. 1962). Another task was to study the reliability of 'electron microscope stains' on a material which is chemically defined.

\section{METHODS}

Organism. Bacillus megaterium strain м (kindly provided by Dr C. Weibull, Stockholm) was used. An $18 \mathrm{hr}$ meat infusion peptone agar culture was harvested into $0.06 \mathrm{M}$-phosphate buffer $\left(\mathrm{pH}_{7 \cdot 2}\right)$, sedimented by centrifugation and used for further treatment.

Experiments with whole organisms. The pellet of bacilli was fixed with $3 \%(\mathrm{w} / \mathrm{v})$ glutaraldehyde (Eastman Kodak, biological grade) in $0.06 \mathrm{M}$-phosphate buffer ( $\mathrm{pH} 7 \cdot 2$ ) for 3-5 hr at room temperature (Fahimi \& Drochmans, 1965), washed many times (or overnight) with phosphate buffer, embedded in $2 \%$ Noble agar, dehydrated and embedded in Vestopal according to Ryter \& Kellenberger (1958 a). Polymerization was done at $60^{\circ}$ for 3 days, sections cut on an MT-I Porter-Blum ultramicrotome and post-stained in the following ways: $(a)$ I $\%(\mathrm{w} / \mathrm{v})$ uranyl acetate $(\mathrm{pH} 4 \cdot 5)$ for $50 \mathrm{~min}$.; (b) I $\%(\mathrm{w} / \mathrm{v}$ ) phosphomolybdate ( $\mathrm{pH} 7 \cdot 2$ ) for $20 \mathrm{~min}$.; (c) I \% (w/v) osmium tetroxide for $60 \mathrm{~min}$. or $4 \%$ osmium tetroxide for $30 \mathrm{~min}$.; $(d) 0.5 \%(\mathrm{w} / \mathrm{v})$ potassium permanganate for $30 \mathrm{~min}$; $(e)$ lead citrate according to Reynolds (1963); $(f)$ 1 \% (w/v) ruthenium red for $45 \mathrm{~min}$. followed by differentiation with acetic acid (Luft, I964); (g) $2 \%(\mathrm{w} / \mathrm{v})$ phosphotungstate $\left(\mathrm{pH}_{7} \cdot 2\right)$ for $20 \mathrm{~min}$.; (h) I \% (w/v) uranyl acetate for 50 min., followed by Reynolds lead citrate; $(i) 4 \%$ (w/v) osmium tetroxide for $30 \mathrm{~min}$. followed by $\mathrm{I} \%(\mathrm{w} / \mathrm{v})$ uranyl ecetate for $30 \mathrm{~min}$; $(j)$ the same as $(i)$ followed by Reynolds lead citrate.

Experiments with isolated cell walls. The preparation, fixation and embedding of cell walls was done as described previously (Nermut, 1965). In some cases additional poststaining was done as described above. 'Mucopeptide membranes' were obtained by boiling bacilli in formamide at $200^{\circ}$ for $4 \mathrm{~min}$. (Nermut, I965). In one experiment a shorter time of extraction was used to determine the localization of the extracted (sensitive) material.

Measurement of the thickness of cell walls or of mucopeptide membranes was done by means of a projector with a micrometric screw which enabled very exact measurements to be made (Profile projector, Nippon Kogaku, K.K.).

Electron microscopy. Preparations were shadowed with platinum or tungsten oxide. Positive staining of cell walls was done by $\mathrm{I} \%(\mathrm{w} / \mathrm{v})$ uranyl acetate treatment for $30 \mathrm{~min}$. followed by washing. Negative staining was done with $\mathrm{I} \%(\mathrm{w} / \mathrm{v})$ phospho- 
tungstate as in the author's modification (Nermut, 1964). Specimens were examined with an electron microscope JEM 6-c (Japan Electron Optics Laboratory) and with the Philips Em Ioo or EM 200.

\section{RESULTS}

\section{Experiments with whole organisms}

Shadowed preparations of Bacillus megaterium organisms did not reveal any conspicuous structure similarly as negatively stained bacilli where only mesosomes were clearly seen. This showed that the cell wall was easily penetrated by phosphotungstate, which was not the case with Gram-negative bacteria (Nermut, I964).

Sections of bacilli fixed with glutaraldehyde showed little or no contrast, but when the negatives were printed on an extra-hard photographic paper the structure of the cell wall and individual ribosomes could be distinguished. (Pl. I, fig. I). The cell wall consisted of two dark lines with a light interspace; the total thickness was about I60 $\AA$.

However, sections poststained with uranyl acetate revealed homogeneous cell walls without any 'layering', 200-240 $\AA$ in thickness. The contours of the cell walls were often uneven and their thickness sometimes reached $300 \AA$ or more (P1. I, fig. 2). This phenomenon may have been due to the presence of a microcapsule, which could be stained by uranyl acetate but not by osmium tetroxide or permanganate. In some cases the microcapsular layer was clearly seen (Pl. 2, fig. 6).

Lead citrate did not stain the cell wall well; usually a double track was observed, but the ribosomes were very dark under those conditions (P1. I, fig. 3). Ruthenium red, reported by Luft (1964) to have affinity for polysaccharides, stained the cell walls and the ribosomes, even though not providing much contrast ( $\mathrm{Pl}$. 2, fig. 4). Interesting results were obtained with phosphotungstic acid and phosphomolybdic acid; in most cases the cell walls were stained homogeneously, as after uranyl acetate, and measured about 200-250 $\AA$ (Pl. 2, fig. 5). The cytoplasmic membrane was represented by a narrow light zone, demonstrating that the lipids were extracted during dehydration. In some cases a loose superficial material with holes could be seen which suggested a microcapsule (Pl. 2, fig. 6). The whole profile measured in this case about $400 \AA$, and the cell wall proper was only $200 \AA$ thick.

With osmium tetroxide and with potassium permanganate the cell wall was limited by two distinct tracks about $160-200 \AA$ apart (PI. 2, fig. 7). With permanganate the interspace showed no electron-dense material. Further poststaining with uranyl acetate revealed a picture very like that after uranyl acetate alone; the cell wall measured then about $240 \AA$ (Pl. 2, fig. 8).

Thus it was shown that the 'triple layered' cell wall in Bacillus megaterium was observed only when the walls were stained by osmium or permanganate. Better contrast was obtained by poststaining with lead citrate (Fig. I). These results suggest a certain unreliability of the mentioned contrasting agents as far as the distribution of substance and the number of cell wall layers are concerned. Observations at high magnification made possible in some cases a detailed study of the cell walls; P1. 2, fig. 9 and Pl. 3, fig. Io are examples of this. On both photographs fine 'channels' could be observed, represented by light 'spaces' of about $\mathrm{I}_{5-25} \AA$ on section, and of different lengths. They do not penetrate the cell wall in a direct way. They are very clearly seen, particularly in Pl. 2, fig. 9 (arrow). The dense granules or areas surrounding the 'channel' were of various shape and size. They usually measured 25-35 $\AA$, but larger 
structures were up to $50 \AA$. It is a question whether the dark structures represented sections through polymer fibres of the cell wall or only precipitated uranium or lead near the real fibres. In any case there were two clearly visible and distinguishable elements in the sections of cell walls: electron-transparent 'areas' and electron-dense granules, rodlets and irregular areas. For comparison an oblique section through a 'mucopeptide membrane' is presented in Pl. 4, fig. I6. The dark granules measure about $20-30 \AA$. Thus, in sections there was no striking difference between the plastic layer and the rigid one. Therefore it is difficult to draw final conclusions about the fine arrangement of the 'building blocks' in the cell wall and one must be reserved when interpreting the electron micrographs.

A

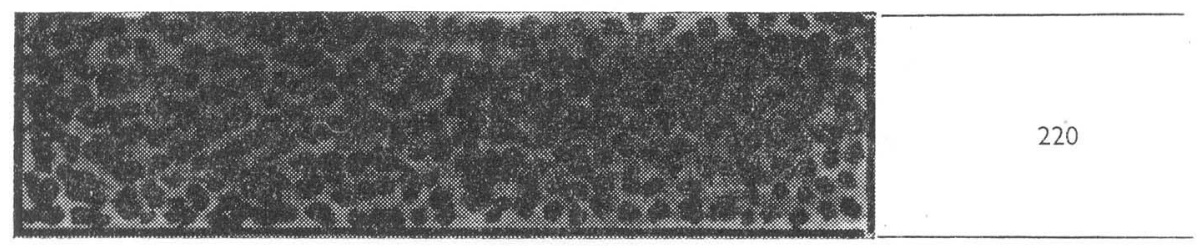

B

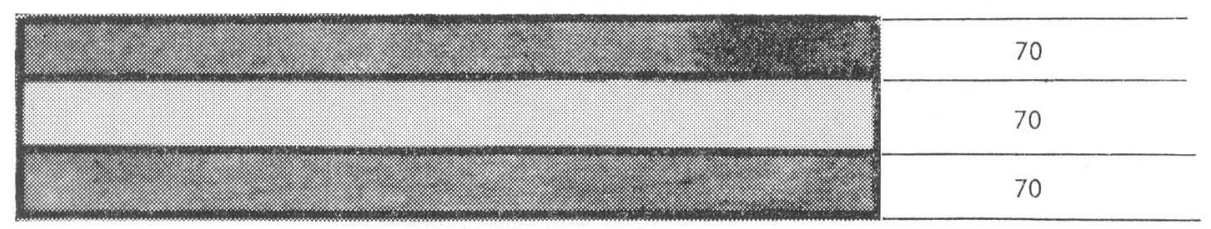

Fig. I. Schematic representation of Bacillus megaterium cell wall fixed with glutaraldehyde and post-stained: A, with uranyl acetate, phosphotungstate, phosphomolybdate or ruthenium red; $\mathbf{B}$, with osmium tetroxide, potassium permanganate or lead citrate.

No boundary could be seen between the two layers, supporting the concept that there is a firm chemical linkage between them. When interpreting the ultrathin sections one must be aware of the difficulties arising from the thickness and orientation of the section. The real arrangement of the cell-wall components could be seen only under ideal conditions, i.e. in very thin sections $(\sim$ IOO $\AA$ ) which were exactly perpendicular to the cell body.

\section{Experiments with isolated cell walls and mucopeptide membranes}

The terms 'layer' and 'membrane' will be used in this paper in the following senses. A layer is a continuous part of the cell wall which can be separated from the outer components of the cell wall. For isolated layers the term 'membrane' has been used when they really form a membrane. Thus the mucopeptide forms a layer within the cell wall, but is called a membrane when isolated.

Shadowed preparations of isolated and purified cell walls did not reveal any con- 
spicuous or regular structure. The same was the case with negatively stained cell walls. More interesting results were obtained when staining the cell walls positively with uranyl acetate. There was a striking difference between the outer and the inner side of the cell wall. The former was dark and 'rough', the latter light and smooth (Pl. 3, fig. II). It is necessary to point out that this staining was done after first drying the cell walls on grids. This might account for the difference in electron density as between the outer and inner parts of the cell wall.

The observations made on sections can be summarized as follows: Uranyl acetate stained the cell wall homogeneously, whereas osmium tetroxide, potassium permanganate or lead citrate produced a 'unit membrane' image. Some sections were post-stained for a longer time with lead citrate so that a superficial loose layer was seen which might represent either the plastic layer or the above mentioned 'microcapsule' (Pl. 3, fig. I2). A detail of the same cell wall showing a 'unit membrane' about $100 \AA$ thick is shown in P1. 3, fig. I3. Thus the results with isolated cell walls were practically the same as with whole bacilli.

Boiling bacilli or cell walls in formamide at $200^{\circ}$ for $4 \mathrm{~min}$. was effective in producing delicate rod-shaped membranes (Pl. 4, fig. I4). They were lysed within $8 \mathrm{~min}$. by $200 \mu \mathrm{g}$. lysozyme $/ \mathrm{ml}$. (observed by nephelometry) and therefore were presumed to be mucopeptide. To determine the location of the plastic layer (removed by formamide), shorter extraction times were used (I.5 and 2.5 min.). Shadowed preparations made from specimens so treated showed irregular remnants or a coarse surface of the cell walls, but it was not easy to make any definite decision about the location of the remnants. Better results were obtained with sections, where it was evident (in some cases) that the material was being extracted from the outermost zone (Pl. 4, fig. 15). After extraction for 4-5 min. the mucopeptide membranes were free from remnants. There was no basic difference among the contrasting agents in staining the mucopeptide membranes (in sections). Mostly only one dark track was observed, about Ioo $\AA$ thick.

With a high-resolution electron microscope (EM 200) we hoped to find structural details in the rigid layer, particularly in oblique sections ( $\mathrm{Pl}$. 4, fig. I6), but it was difficult to find a regular pattern. The most important question is whether the dark points or spots represented the cross-sections of polymer fibres or only granules of osmium or lead. This is not yet clear and our conclusions about the ultrastructure of the rigid layer remain uncertain.

The measurement of thickness of the cell wall in sections is charged with error, in spite of accurate measurement by means of a projector. The difficulties arise from the fact that not all the measured cell walls were cut perpendicularly. Every deviation from the perpendicular plane distorts the results (Lickfeld, 1965). Although more than 50 cell walls and 50 mucopeptide membrane were measured, the results were not statistically evaluated. The thickness of the cell wall ranged from 2 ro to $240 \AA$, that of the 'mucopeptide membranes' from 80-I Io $\AA$. The average thickness was near $220 \AA$ for the cell wall and near $100 \AA$ for the 'mucopeptide membranes'. This means that the mucopeptide membrane occupied about $45 \%$ of the cell-wall width. 


\section{DISCUSSION}

Extraction of Bacillus megaterium cell walls with hot formamide decreased their thickness by about $50 \%$. This supports the concept that the cell wall is made up of two layers which can be separated. The mucopeptide rigid layer is resistant to hot formamide extraction and forms a rod-shaped membrane about $100 \AA$ thick. The plastic mucopolysaccharide layer, which is dissolved by hot formamide, is situated outside the rigid layer. This type of result has not always been obtained. For example Archibald et al. (196I) did not find any difference in 'submicroscopic appearance' of cell-wall sections of Bacillus subtilis and a Lactobacillus sp. before and after extraction with cold trichloroacetic acid. In both cases the walls were 'triple-layered' after permanganate fixation, however, no exact data about their thickness was given. In addition, permanganate is not very reliable in staining the cell-wall substance, and it

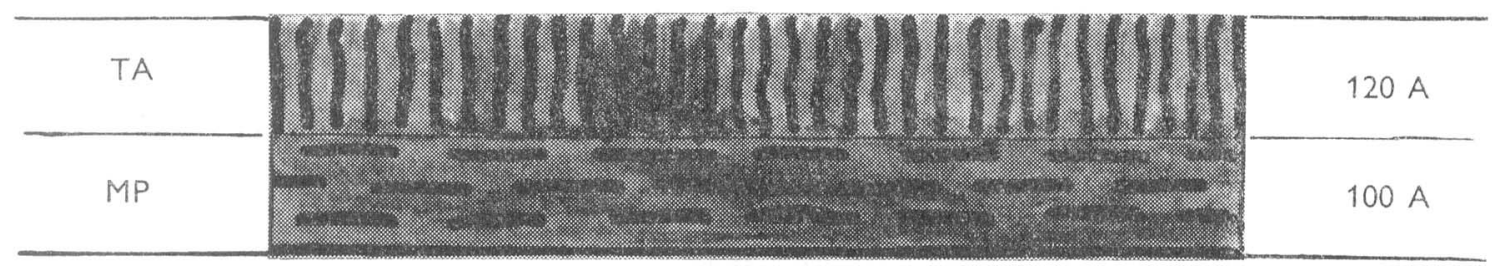

Fig. 2. A tentative scheme of the cell wall of Bacillus megaterium showing a rigid mucopeptide layer (MP) and a 'plastic' layer formed by teichoic acid bristles' (TA).

seems to give a precipitate on the surface of membranes, irrespective of their chemical composition (Bradbury \& Meek, 1960). Ghuysen et al. (I962) found that the teichoic acid of $B$. megaterium was not completely extracted by cold trichloroacetic acid and that complete removal required specific enzyme or hot formamide. Krause \& McCarty (I96I) made a similar observation with streptococci. For the same reason the results obtained by using the method of Park \& Hancock (1960), were not satisfactory as the hot formamide extraction of membranes obtained by this procedure solubilized some more hexosamines (about $40 \%$ according to Nermut \& Svobodová, 1965). In the present experiments, sections through cell walls extracted for shorter times showed that the teichoic acid lay on the outer side of the rigid layer. Thus, there is some analogy with Gram-negative cell walls, where the innermost position of mucopeptide layer has been demonstrated by Bladen \& Mergenhagen (1964) and Murray, Steed \& Elson (1965).

Uncertainties surround the presence of microcapsular material, which could be seen in some cases and which very probably caused the increase in thickness up to $300-400 \AA$. No special structured protein layer could be found as was observed in Bacillus polymyxa (Nermut \& Murray, 1967). For this reason it is assumed that the cell wall of $B$. megaterium represents a 'basic Gram-positive cell wall' built up of two closely placed layers, one of them being rigid and the other plastic (Fig. 2). This is supported by the chemical analysis by Ghuysen et al. (I962), which showed that the mucopeptide and the mucopolysaccharide were in equimolar proportion. The plastic layer of B. megaterium is represented by short chains perpendicular to the cell surface. There are several reasons for this type of arrangement. The plastic layer cannot be isolated as a membrane, as can the mucopeptide one. This means that there are probably no, 
or very weak, side links between the fibres of the teichoic acid. The surface of the cell walls is coarse rather than smooth. No regularity was observed in sections, either longitudinal or transverse. This again speaks in favour of the plasticity, or at least the non-rigidity, of this layer.

The idea of the perpendicular orientation of teichoic acid fibrils is supported by the results of Ghuysen et al. (1962), who established that the teichoic acid from Bacillus megaterium cell wall was built up of Io subunits. Similar results with other organisms were reported by Armstrong, Baddiley \& Buchanan (1960) and Hay et al. (1965). Thus in lactobacilli the teichoic acid is made up of 7.6 units, in staphylococci of $8 \cdot I$ and in $B$. subtilis of 8.9 units. It seems very probable that in $B$. megaterium the chain of a Io-unit teichoic acid is attached to the mucopeptide by one phosphate group (phosphoramidate linkage according to Hay et al. 1965) and the other group lies free on the surface, so contributing to the negative charge of the cell wall (Rogers, I962). There is no direct evidence for this idea from our sections. It is very difficult to find an exactly perpendicular section (either to the long or short axis) which is also very thin where the parallel 'bristles' of teichoic acid could be seen. The other difficulty arises from the flexibility or plasticity of the teichoic acid fibres, which can collapse upon drying so that any regularity is disturbed. The length of teichoic acid composed of Io units is estimated to be about IOO-I $20 \AA$ (Dr H. J. Rogers, personal communication), which corresponds very well with our findings. Application of freeze-etching method could probably help to solve this problem. Fibrils in the cell walls of $B$. cereus were recently described by Remsen (I966).

The presence of irregular 'channels' accounts for the good permeability (or penetrability) of Bacillus megaterium cell walls for phosphotungstic acid or larger molecules (Gerhardt \& Judge, 1964). As the chemistry is not the main topic of this paper, the question of the type of linkage of teichoic acid to the mucopeptide has not been discussed in more detail.

Post-staining of glutaraldehyde-fixed bacilli or cell walls with various metal compounds showed that one cannot speak of a 'triple layered' or 'trilaminate' cell wall if this is based on staining by osmium, permanganate or lead only. We were able to show that 'unit membranes' can be produced by all these agents, particularly by poststaining with lead (PI. 3, fig. I3); this happens even with material which does not contain any lipids or lipoproteins. Obviously other chemical groups are responsible for the reduction of osmium tetroxide or potassium permanganate in this case (Bahr, 1954). The most reliable view of the disposition of cell-wall material is given by uranyl acetate because of its low specificity (binding occurs with both phosphate groups and carboxyl groups; Elbers, 1964). A similar conclusion was drawn from parallel observation on Bacillus polymyxa (Nermut \& Murray, 1967).

This paper is dedicated to the memory of Professor F. Herčík, my first teacher in science.

The first series of experiments (with isolated cell walls) described here was done at the Institute for Microbiology and Experimental Therapy in Jena (German Democratic Republic) in 1964. The author wishes to thank Miss E. Fritsche and Mrs M. Völkel for technical cooperation. Experiments with whole organisms were made at the Department of Bacteriology and Immunology, University of Western Ontario, London, Canada, and the author thanks Professor R. G. E. Murray for critical 
suggestions about the paper and Mrs M. Hall and Mr J. Marak for excellent technical help. Critical comments and suggestions by Dr E. Work (Twyford Laboratories, London, England) and Dr A. M. Glauert (Strangeways Research Laboratory, Cambridge, England) are greatly acknowledged.

A part of the work reported here was supported by the grant no. ${ }^{3} 322-\mathrm{N} 54$ of the Medical Research Council of Canada.

\section{REFERENCES}

Archibald, A. R., Armstrong, J. J., Baddiley, J. \& Hay, J. B. (I961). Teichoic acids and the structure of bacterial cell walls. Nature, Lond. I91, 570.

Armstrong, J. J., Baddiley, J. \& Buchanan, J. G. (1960). Structure of the ribitol teichoic acid from the walls of Bacillus subtilis. Biochem. J. 76, 610.

BAHR, G. F. (1954). Osmium tetroxide and ruthenium tetroxide and their reactions with biologically important substances. Expl. Cell Res. 7, 457.

Bladen, H. A. \& Mergenhagen, S. E. (1964). Ultrastructure of Veillonella and morphological correlation of an outer membrane with particles associated with endotoxic activity. J. Bact. 88, I482.

Bradbury, S. \& Meek, G. A. (1960). A study of potassium permanganate 'fixation' for electron microscopy. Q.J. microbiol. Sci. ror, $24 \mathrm{I}$.

Colobert, L. \& Creach, O. (I96I). La paroi ectoplasmique des bactéries. Path. Biol., Paris 9, 36I.

Czerkawski, J. W., Perkins, H. R. \& Rogers, H. J. (I963). A study of the composition and structure of the cell wall mucopeptide of Micrococcus lysodeikticus. Biochem. J. 86, 468.

Elbers, P. F. (1964). The cell membrane: image and interpretation. In Recent Progress in Surface Science. Ed. by J. F. Danielli, K. G. A. Pankhurst and A. C. Riddiford, vol. II, p. 443. New York and London: Academic Press Inc.

Ellwood, D. C., Kelemen, M. V. \& Baddiley, J. (1963). The glycerol teichoic acid from the walls of Staphylococcus albus NCTC 7944. Biochem. J. 86, 213.

Fahimi, H. D. \& Drochmans, P. (1965). Essais de standardisation de la fixation au glutaraldéhyde. II. Influence des concentrations en aldéhyde et de l'osmolalité. J. Microscopie 4, 737.

FulLER, A. T. (1938). The formamide method for the extraction of polysaccharides from haemolytic streptococci. Br. J. exp. Path. 19, I30.

Gerhardt, P. \& Judge, J. A. (1964). Porosity of isolated cell walls of Saccharomyces cerevisiae and Bacillus megaterium. J. Bact. 87, 945.

GhuYsen, J. M. (196I). Complexe acide teichoique-mucopeptide des parois cellulaires de Bacillus megaterium Kм. Biochim. biophys. Acta 50, $4 \mathrm{I} 3$.

Ghuysen, J. M., Leyh-Bouille, M. \& Dierickx, L. (I962). Structure des parois de Bacillus megaterium KM. II. Étude des complexes mucopeptidique et phosphomucopolysaccharidique. Biochim. biophys. Acta 63, 297.

HAY, J. B., ARChibald, A. R. \& BADdiley, J. (1965). The molecular structure of bacterial walls. The size of ribitol teichoic acids and the nature of their linkage to glycosaminopeptides. Biochem.J. 97, 723 .

KNOX, K. \& Hall, E. (1965). Evidence for the linkage between the polysaccharide and mucopeptide components of the cell wall of Lactobacillus casei. Biochem. J. 95, 48.

Krause, R. M. \& McCARTY, M. (I961). Studies on the chemical structure of the streptococcal cell wall. I. The identification of a mucopeptide in the cell walls of group A and A-variant streptococci. J. exp. Med. 114, I27.

LICKFELD, K. G. (1965). Sichtbarkeit und Dicke konzentrischer Membranen stäbchenförmiger Bakterien im ultradünnen Längsschnitt. Zentbl. Bakt. I. Orig. 196, 520.

LUFT, J. H. (1964). Electron microscopy of cell extraneous coats as revealed by ruthenium red staining. J. Cell Biol. 23, I09.

Martin, H. H. (I966). Biochemistry of bacterial cell walls. A. Rev. Biochem. 35, 457.

MurRay, R., SteEd, P. \& Elson, H. (1965). The location of the mucopeptide in sections of the cell wall of Escherichia coli and other Gram-negative bacteria. Can. J. Microbiol. xI, 547.

Nermut, M. V. (1964). Bacterial surfaces as revealed by the negative staining method. Proc. $3 \mathrm{rd}$ Europ. Reg. Conf. EM, Prague, vol. B, p. 525. 
Journal of General Microbiology, Vol. 49, No. 3

Plate I
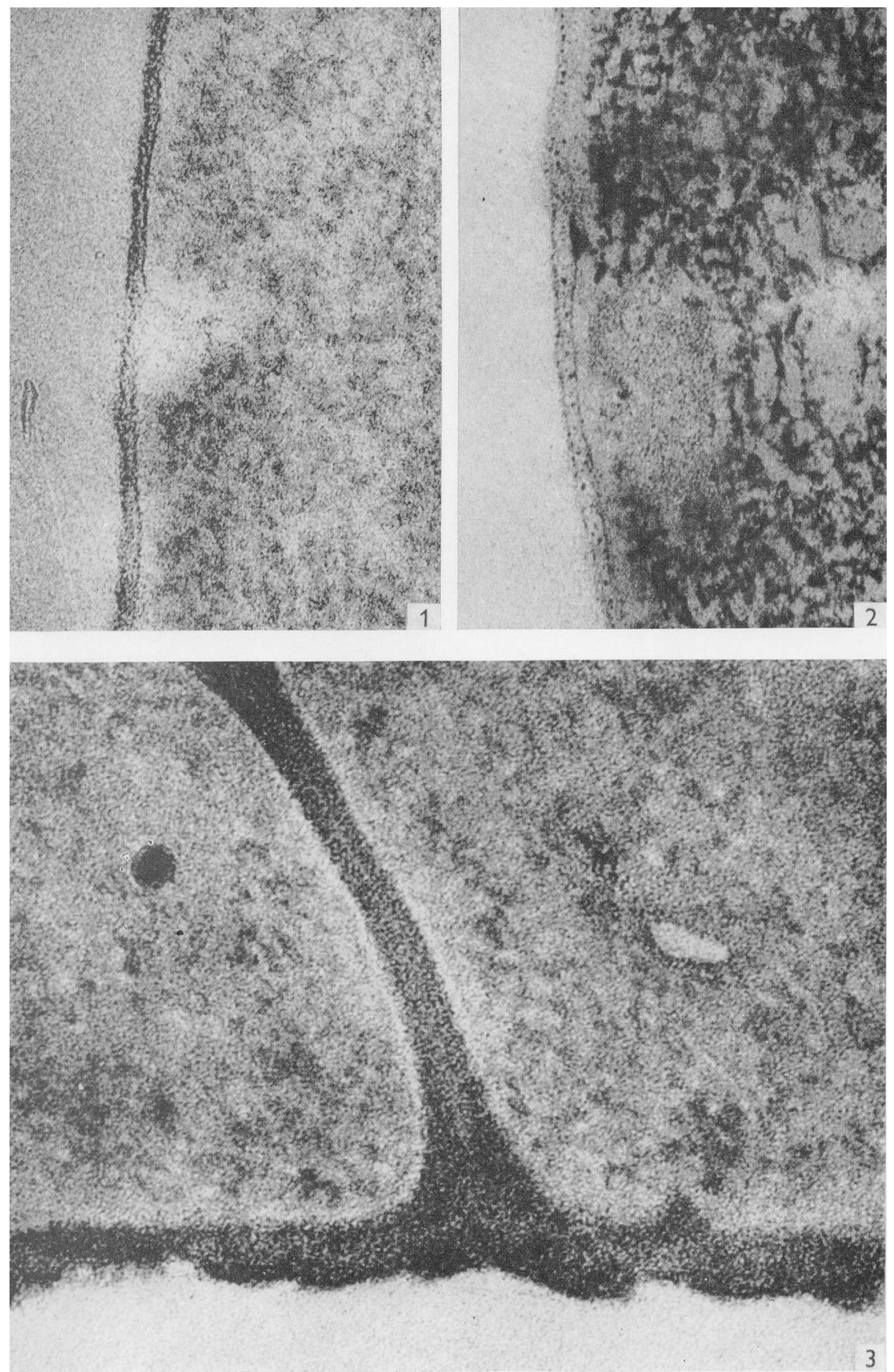
Journal of General Microbiology, Vol. 49, No. 3

Plate 2
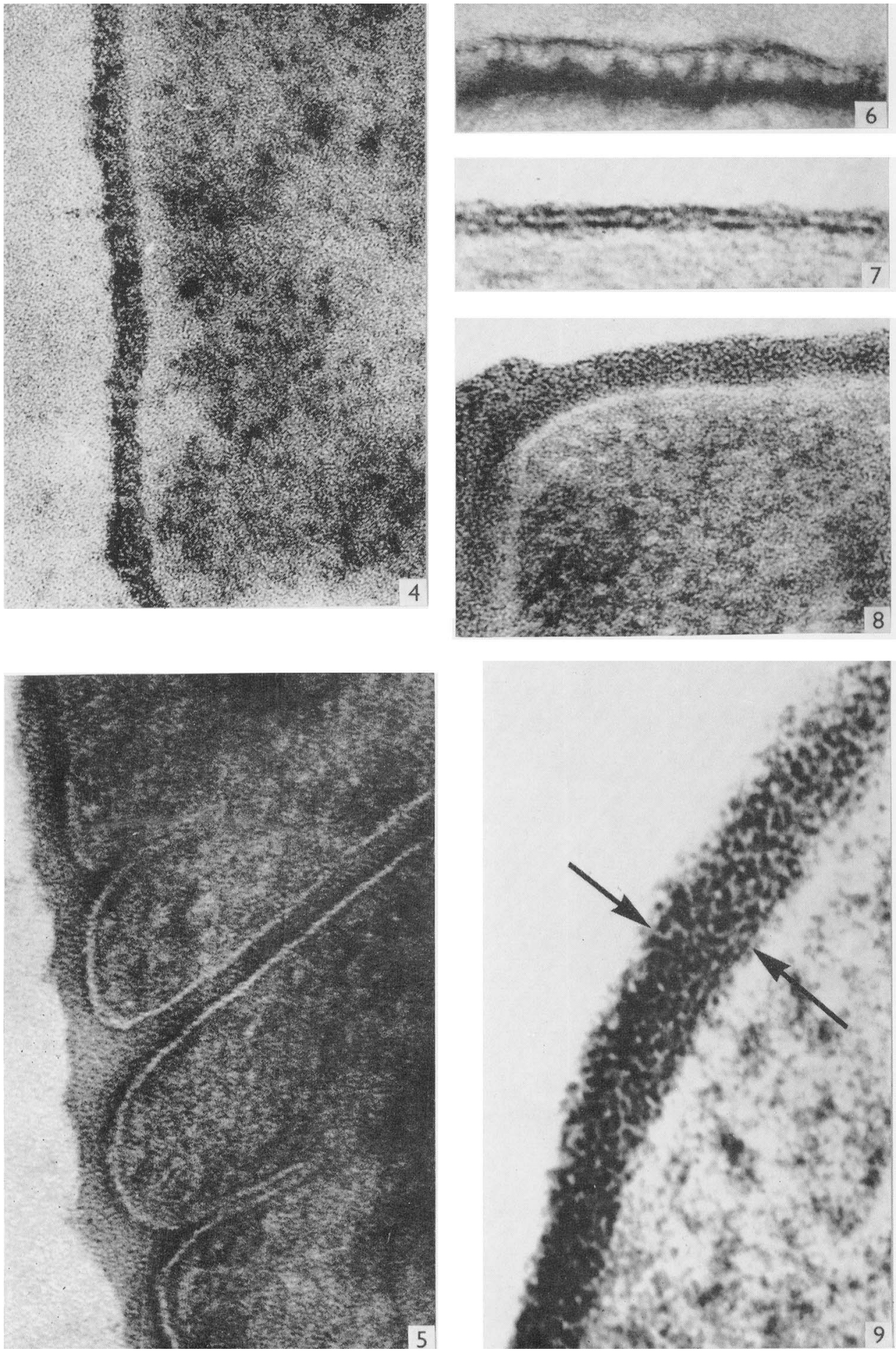

M. V. NERMUT 
Journal of General Microbiology, Vol. 49, No. 3

Plate 3
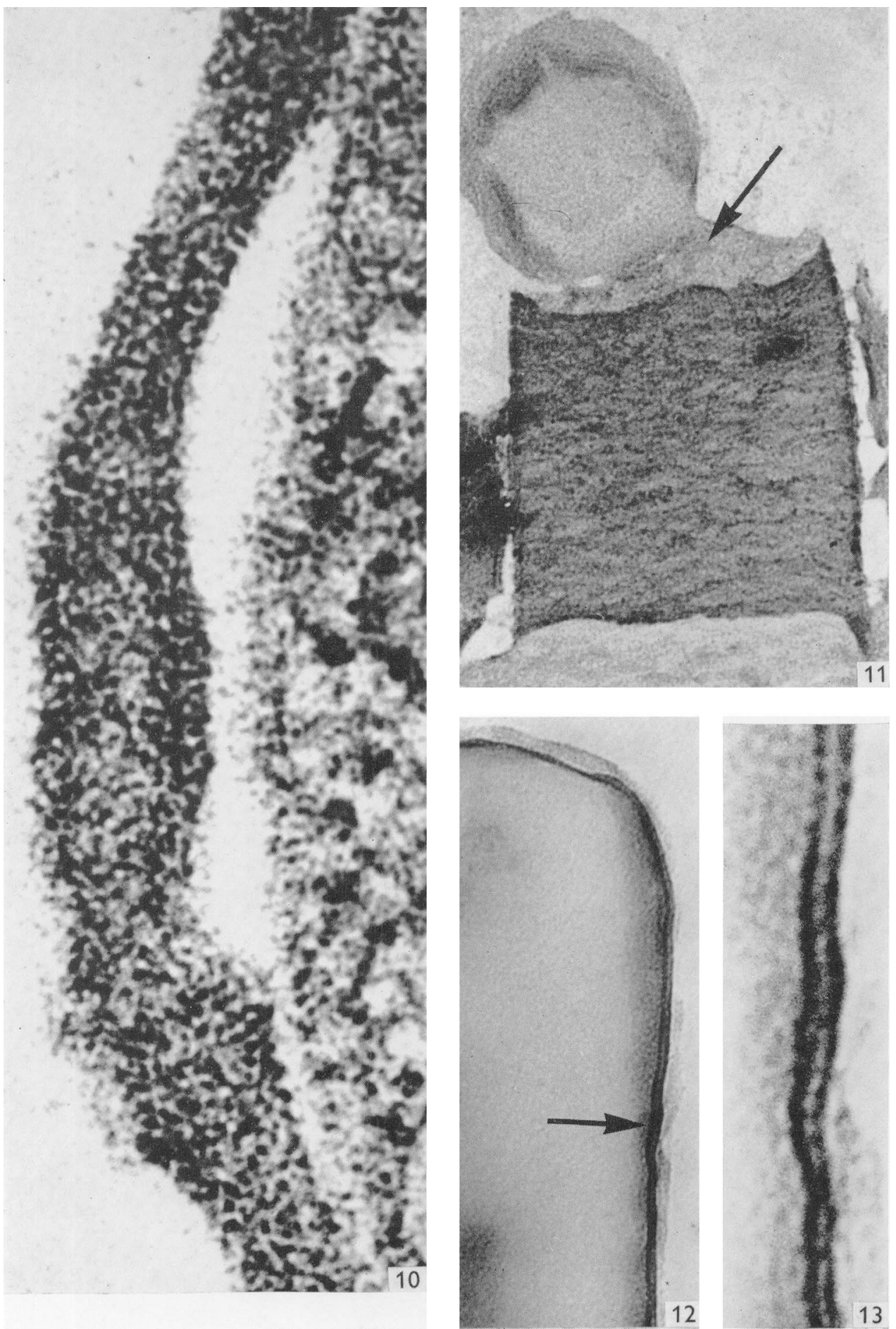

M. V. NERMUT 
Journal of General Microbiology, Vol. 49, No. 3

Plate 4
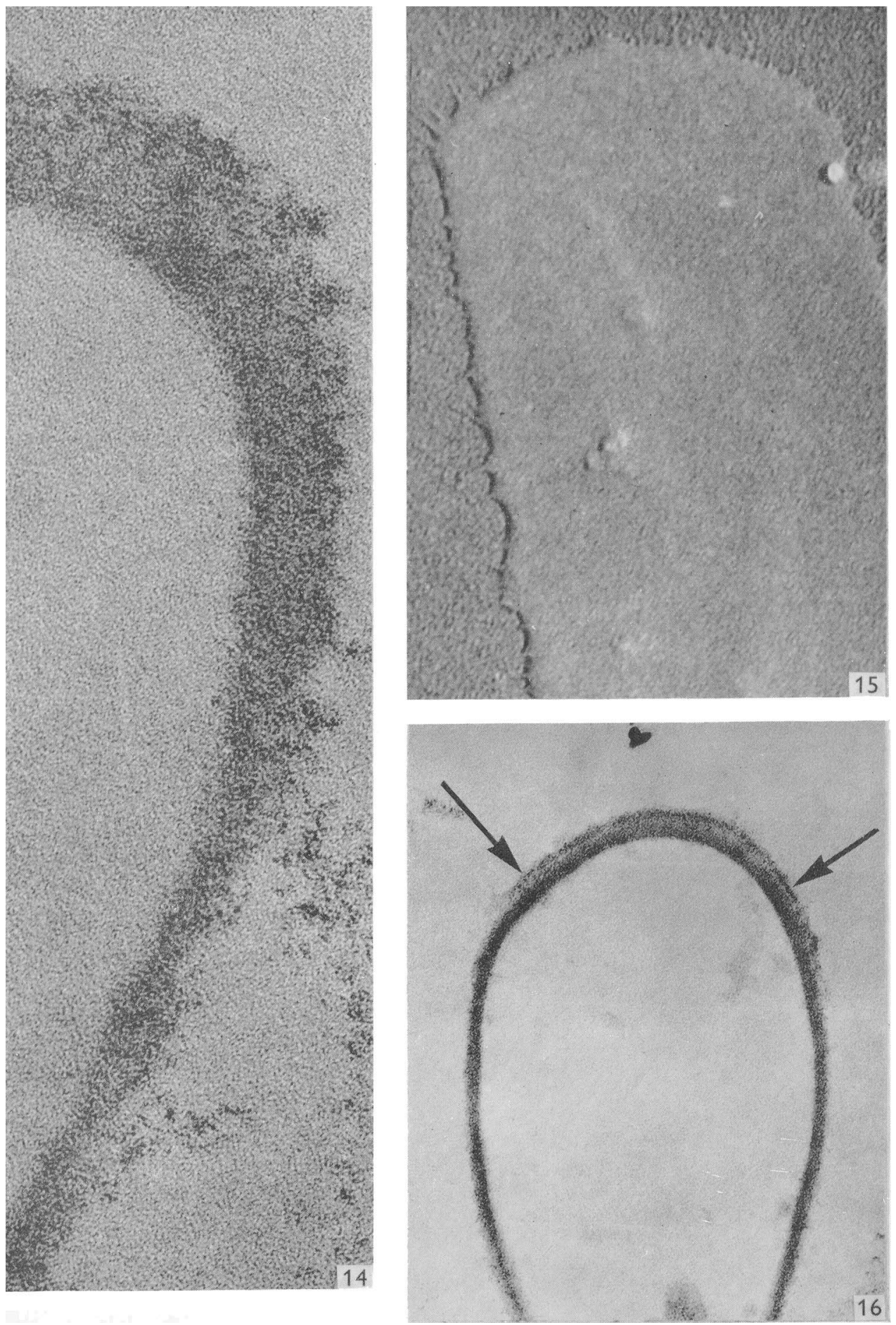

M. V. NERMUT 
Nermut, M. V. (1965). Effect of hot formamide on Gram-positive and Gram-negative cell walls. Experientia 21, 502.

Nermut, M. V. \& Svobodová, V. (I965). Alcian blue staining of bacterial cell walls. Z. allg. Microbiol. $5,378$.

Nermut, M. V. \& Murray, R. G. E. (1967). The ultrastructure of the cell wall of B. polymyxa. J. Bact. 93, 1949.

PARK, J. T. \& HANCOCK, R. (I960). A fractionation procedure for studies of the synthesis of cell-wall mucopeptide and of other polymers in cells of Staphylococcus aureus. J. gen. Microbiol. 22, 249.

Remsen, C. C. (1966). The fine structure of frozen-etched Bacillus cereus spores. Arch. Mikrobiol. 54, 266.

ReYNolds, E.S. (I963). The use of lead citrate at high $\mathrm{pH}$ as an electron-opaque stain in electron microscopy. J. Cell Biol. r9, 208.

Rogers, H. J. (1962). The surface structures of bacteria. Biochem. Soc. Symp. no. $22,55$.

Ryter, A., Kellenberger, E. (1958a). Inclusion au polyester. Quatrième congrès international de microscopie électronique. Berlin, September 1958, p. 52.

Ryter, A. \& Kellenberger, E. (I958b). Etude au microscope électronique de plasmas contenant de l'acide déoxyribonucléique. $Z$. Naturforsch. $\mathbf{1 3}_{3} b, 597$.

Salton, M. R. J. (I960). Microbial Cell Walls. New York and London: John Wiley and Sons Inc.

Salton, M. R. J. (1964). The Bacterial Cell Wall. Amsterdam, London, New York: Elsevier Publishing Company.

Strominger, J. L. \& Ghuysen, J. M. (1963). On the linkage between teichoic acid and the glycopeptide in the cell wall of Staphylococcus aureus. Biochim. Biophys. Res. Commun. 12, 4I8.

Weidel, W. \& Pelzer, H. (1964). Bagshaped macromolecules. A new outlook on bacterial cell walls. Advanc. Enzymol. 26, 193.

WoRk, E. (196I). The mucopeptides of bacterial cell walls. A review. J. gen. Microbiol. $25,167$.

\section{EXPLANATION OF PLATES}

All micrographs are of Bacillus megaterium or its fractions.

\section{Plate I}

Figs. I-9. Sections of Bacillus megaterium fixed with glutaraldehyde and post-stained on sections as indicated.

Fig. 1. No post-staining, printed on an extra-hard photographic paper. $\times 120,000$.

Fig. 2. Post-stained by lead citrate. $\times 120,000$.

Fig. 3. Post-stained by uranyl acetate. The cell wall and the septum are dense (dark); no layering observable. The outer edge is uneven. $\times 200,000$.

\section{Plate 2}

Fig. 4. Post-stained by ruthenium red. $\times 170,000$.

Fig. 5. Post-stained by phosphomolybdate. General appearance is very similar to that of uranyl acetate stained cells. $\times 200,000$.

Fig. 6. Post-stained by phosphotungstate. The proper cell wall is dark and homogeneous. The holey part is probably a microcapsule. $\times 200,000$.

Fig. 7. A part of the cell post-stained by osmium tetroxide showing a 'triple layered' cell wall. $\times 200,000$.

Fig. 8. Post-staining by osmium tetroxide and uranyl acetate. $\times 200,000$.

Fig. 9. A detail of a cell wall; post-stained by uranyl acetate followed by lead citrate. Irregular 'channels' connecting the outer and inner surface can be found in the wall (arrow). $\times 500,000$.

\section{Plate 3}

Fig. 10. A detail of a cell wall fixed and post-stained as in Fig. $9 . \times 500,000$.

Fig. I I. Isolated cell wall dried on grid and stained $30 \mathrm{~min}$. with $\mathrm{I} \%$ uranyl acetate. Note the difference between the surface and the inner side (arrow). $\times 30,000$. 
Fig. I2. Isolated cell wall fixed with glutaraldehyde, post-stained by lead citrate. After prolonged lead staining two parts can be distinguished. The inner one has a unit membrane structure (arrow). $\times 100,000$.

Fig. 13. Enlarged portion of the cell wall of fig. 12 indicated by arrow. $\times 500,000$.

\section{Plate 4}

Fig. 14. Detail of an oblique section of an incompletely extracted cell wall treated with hot formamide for $2.5 \mathrm{~min}$. Same fixation as in fig. $15 . \times 300,000$.

Fig. 15. 'Mucopeptide membrane' obtained by formamide extraction. Shadowed. $\times$ 100,000.

Fig. I6. Section of a cell wall extracted $\mathrm{I} \cdot 5 \mathrm{~min}$. only with hot formamide. The formamide sensible 'layer' remains on the outer part of the cell wall (arrows). Fixed with Ryter \& Kellenberger fixative $(1958 b) . \times 100,000$. 